\title{
Structure of Biologically Active Benzoxazoles: Crystallography and DFT Studies
}

\section{Una Glamočlija, ${ }^{1,2, \star}$ Selma Špirtović-Halilović, ${ }^{3}$ Mirsada Salihović, ${ }^{4}$ Iztok Turel, ${ }^{5}$ Jakob Kljun, ${ }^{5}$ Elma Veljović, ${ }^{3}$ Selma Zukić ${ }^{3}$ and Davorka Završnik ${ }^{3}$}

${ }^{1}$ Department for Biochemistry and Clinical Analysis, Faculty of Pharmacy, University of Sarajevo, Zmaja od Bosne 8, 71000 Sarajevo, Bosnia and Herzegovina

${ }^{2}$ School of Medicine, University of Mostar, Zrinskog Frankopana 34, Mostar 88000, Bosnia and Herzegovina

${ }^{3}$ Department of Pharmaceutical Chemistry, Faculty of Pharmacy, University of Sarajevo, Zmaja od Bosne 8, 71000 Sarajevo, Bosnia and Herzegovina

${ }^{4}$ Department of Natural science, Faculty of Pharmacy, University of Sarajevo, Zmaja od Bosne 8, 71000 Sarajevo, Bosnia and Herzegovina

${ }^{5}$ Faculty of Chemistry and Chemical Technology, University of Ljubljana, Večna pot 113, 1000 Ljubljana, Slovenia

* Corresponding author: E-mail: una.glamoclija@ffsa.unsa.ba,

Received: 07-02-2020

\begin{abstract}
Using X-ray single crystal diffraction, the crystal structures of biologically active benzoxazole derivatives were determined. DFT calculation was performed with standard $6-31 G^{*}(d), 6-31 G^{* *}$ and $6-31+G^{*}$ basis set to analyze the molecular geometry and compare with experimentally obtained X-ray crystal data of compounds.

The calculated HOMO-LUMO energy gap in compound 2 (2-(2-hydroxynaphtalen-1-yl)-4-methyl-7-isopropyl-1,3-benzoxazol-5-ol) is $3.80 \mathrm{eV}$ and this small gap value indicates that compound 2 is chemically more reactive compared to compounds 1 (4-methyl-2-phenyl-7-isopropyl-1,3-benzoxazol-5-ol) and 3 (2-(4-chlorophenyl)-4-methyl-7-isopropyl-1,3-benzoxazol-5-ol). The crystal structures are stabilized by both intra- and intermolecular hydrogen bonds in which an intermolecular $\mathrm{O}-\mathrm{H} \cdots \mathrm{N}$ hydrogen bond generates $\mathrm{N} 3$ and $\mathrm{O} 7$ chain motif in compounds 1, 2, and 3, respectively. The calculated bond lengths and bond angles of all three compounds are remarkably close to the experimental values obtained by X-ray single crystal diffraction.
\end{abstract}

Keywords: Benzoxazole; X-ray diffraction; DFT calculation

\section{Introduction}

Benzoxazoles are compounds with a wide range of biological activities and represent a very important structural motif in medicinal chemistry. Benzoxazole ring can be found in natural and synthetic compounds used as pharmaceuticals. ${ }^{1}$ Caboxamycin (Figure 1a) is a new antibiotic of the benzoxazole family produced by the deep-sea strain Streptomyces sp. NTK 937. ${ }^{2}$ Figure 1b presents the synthetic compound with a two times better Pseudomonas aeruginosa inhibitory activity than ampicillin and streptomycin. ${ }^{3}$ Benzoxazoles have anti-inflammatory, ${ }^{4}$ antimicrobial, $^{5-7}$ and antitumor ${ }^{6-10}$ activities. a)
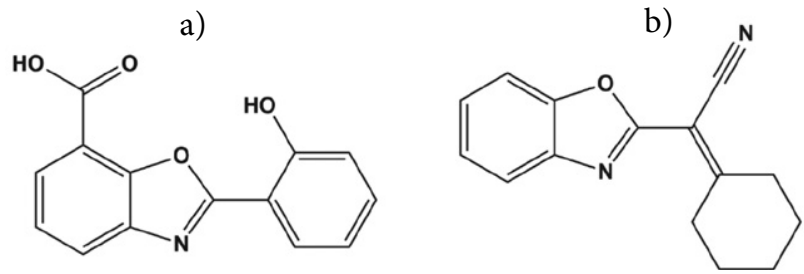

Figure 1. Structure of Caboxamycin (a) and (b) a synthetic derivative of benzoxazole.

Benzoxazoles have a certain structural similarity with nucleic bases such as adenine and guanine, and they interact with biopolymers in living organisms. ${ }^{2}$ The mole- 
cule is planar with conjugated sextets of $\pi$ electrons in the cyclic system. ${ }^{11}$ They have aromatic properties and are quite stable. Benzoxazoles are sensitive to hydrolysis which leads to ring-opening. Depending on substituents, different conditions of media and $\mathrm{pH}$ values lead to hydrolysis. ${ }^{11-14}$ While unsubstituted benzoxazole is resistant to hydrolysis in alkaline medium, rapid hydrolysis occurs in acidic medium, probably due to nucleophilic attack (Scheme 1). ${ }^{11}$ Hydrolysis can be seen in vivo, as Bray et al. (1952) have shown in experiments on rabbits. They evaluated the metabolism of benzoxazole, 2-methylbenzoxazole, and 2-phenylbenzoxazole and found that the stability of the ring depends on substituents. Benzoxazole and 2-methylbenzoxazole mainly hydrolyzed in organisms while the ring in 2-phenylbenzoxazole is stable and mainly metabolized by hydroxylation of phenyl group at the position $2 .^{\prime 12}$

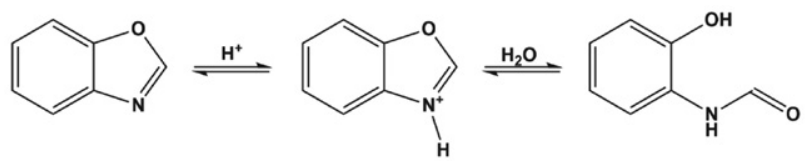

Scheme 1. Hydrolysis of benzoxazole ring in acidic conditions.

Hydrolysis of drugs containing benzoxazole rings can have pharmaceutical importance. It can result in the formation of active compounds that can be directly delivered to the site of interest. ${ }^{13}$ The stability and reactivity of benzoxazoles are crucial for their medicinal applications. Density functional theory (DFT) is a very common computational method used to solve Schrödinger and Dirac equations. ${ }^{15}$

In our previous paper, ${ }^{16}$ a library of thymoquinone-derived benzoxazoles has been synthesized and their antiproliferative activities were reported. The starting compound for synthesis was thymoquinone that reacted with sodium azide to obtain aminothymoquinone (ATQ). ATQ reacted with aromatic aldehydes to obtain benzoxazoles. Out of the 10 novel compounds prepared, ${ }^{16}$ in this paper, the structures of three compounds: 1 (4-methyl-2-phenyl-7-isopropyl-1,3-benzoxazole-5-ol), $\quad 2$ (2-(2-hydroxynaphtalen-1-yl)-4-methyl-7-isopropyl-1,3-benzoxazole-5-ol), and 3 (2-(4-chlorophenyl)-4-methyl-isopropyl-1,3-benzoxazole-5-ol) are in the focus. Synthetic details, analytical and spectroscopic data of compounds can be found in our previous paper. ${ }^{16}$

The simultaneous approach of X-ray crystallography and DFT calculation is used. This approach takes advantage of the great interpretive power of theoretical studies and the precision of the experimental method. We report the crystal structure of benzoxazole derivatives, as well as results of theoretical studies using the DFT(B3LYP) method and standards $6-31 G^{*}(d), 6-31 G^{* *}$ and $6-31+G^{*}$ basis set. The aim of the present work was to describe and characterize the molecular structure and some electronic struc- ture properties of the biologically active benzoxazole derivatives by using two approaches: experimental, using X-ray crystallography, and theoretical, using DFT calculation. Finally, the results of the two approaches are compared.

\section{Experimental}

\section{1. Crystallographic Data Collection}

$\mathrm{X}$-ray diffraction data for all compounds was collected on an Oxford Diffraction SuperNova diffractometer with $\mathrm{Cu}$ microfocus $\mathrm{X}$-ray source with mirror optics and an Atlas detector. The structures were solved by direct methods implemented in SHELXT ${ }^{17}$ and refined by a full-matrix least-squares procedure based on $F^{2}$ using SHELXL ${ }^{18}$ within the Olex2 program pack. ${ }^{19}$ All non-hydrogen atoms were refined anisotropically. The hydrogen atoms were placed at calculated positions and treated using appropriate riding models. The programs Platon and Mercury were used for data analysis and figure preparation. ${ }^{20,21}$ The crystal structures have been submitted to the CCDC and have been allocated the deposition numbers 1586630, 1985495, 1985496.

\section{2. Computational Details}

The molecular structures of compounds 1, 2 and 3 were subjected to quantum chemical density functional calculation using the Becke-3Lee-Yang-Parr (B3LYP) hybrid functional with the standards $6-31 \mathrm{G}^{*}(\mathrm{~d}), 6-31 \mathrm{G}^{* *}$ and $6-31+\mathrm{G}^{*}$ basis set. The computations were performed using Spartan 14. The structures are minima on potential energy surface. The calculated values were compared with the obtained experimental results.

\section{Results and Discussion}

The crystal data and structure refinement of compounds 1, 2 and 3 are given in Table 1 and shown in Figure 2. The selected geometric parameters of the same compounds are given in Table 2. The structural parameters were calculated and are presented in Table 3 . The crystal structure of compound 1 (4-methyl-2-phenyl-7-isopropyl-1,3-benzoxazole-5-ol) has been determined by X-ray diffraction in our previous paper. ${ }^{16}$ Previous crystallographic results for this compound are used in this paper for comparison with the DFT results.

The calculated bond lengths and bond angles of 1,2 and $\mathbf{3}$ are remarkably close to the experimental values obtained by X-ray crystal diffraction.

\section{1. Geometrical Parameters Analysis}

Bond lengths of compounds 1,2 and 3 are in the normal range. ${ }^{22}$ The experimentally obtained value of av- 

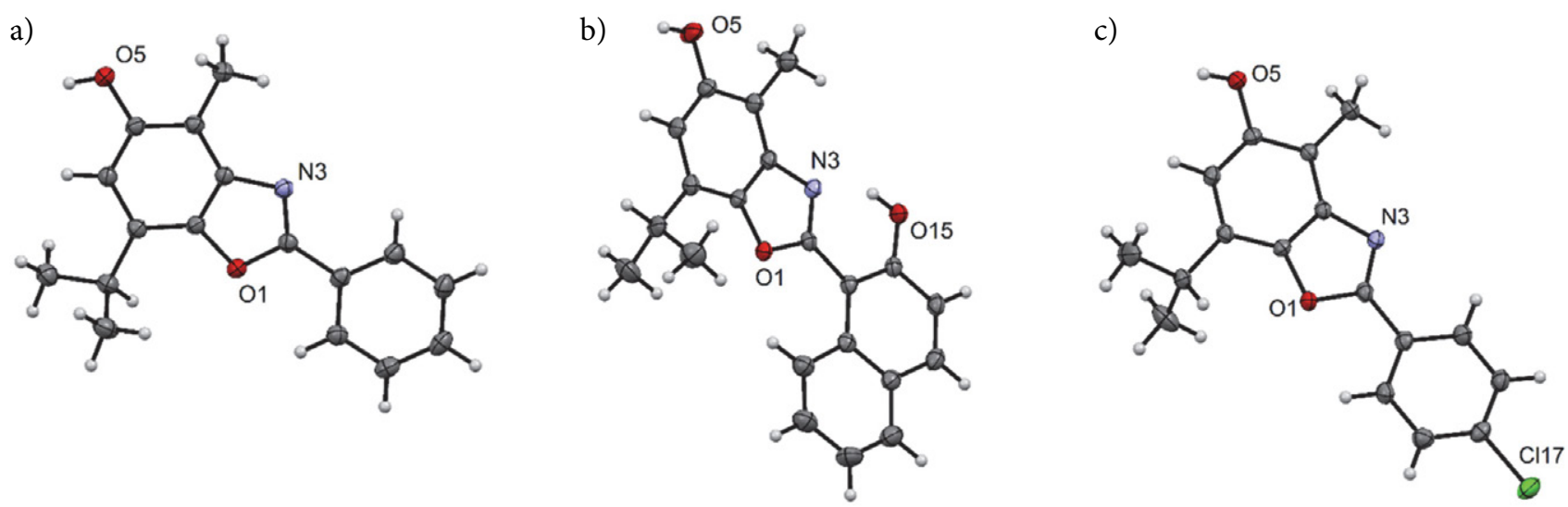

Figure 2. Crystal structures of compounds 1 (a), ${ }^{16} \mathbf{2}$ (b), and 3 (c) with heteroatom labelling. Thermal ellipsoids are drawn at $50 \%$ probability level.

erage mean bond distances were of $\mathrm{C}-\mathrm{C}=1.425 \AA$, $\mathrm{C}-\mathrm{O}$ $=1.373 \AA, \mathrm{C}-\mathrm{N}=1.353 \AA$, for compound $1,{ }^{16} \mathrm{C}-\mathrm{C}=1.424$ $\AA, \mathrm{C}-\mathrm{O}=1.366 \AA, \mathrm{C}-\mathrm{N}=1.348 \AA$, for compound 2 and $\mathrm{C}-\mathrm{C}=1.424 \AA, \mathrm{C}-\mathrm{O}=1.373 \AA, \mathrm{C}-\mathrm{N}=1.355 \AA$, for compound 3 respectively, shown in Table 3 . The bond distances of $\mathrm{C} 2=\mathrm{N} 3$ are $1.302 \AA, 1.307 \AA$ and $1.303 \AA$ for compounds 1,2 and 3 , respectively. They are comparable with the reported double bond lengths. ${ }^{23}$ The theoretically obtained value of average mean bond distances were of $\mathrm{C}-\mathrm{C}$ $=1.433 \AA, \mathrm{C}-\mathrm{O}=1.373 \AA, \mathrm{C}-\mathrm{N}=1.347 \AA$, for compound $1, \mathrm{C}-\mathrm{C}=1.433 \AA, \mathrm{C}-\mathrm{O}=1.366 \AA, \mathrm{C}-\mathrm{N}=1.353 \AA$, for compound 2 and $\mathrm{C}-\mathrm{C}=1.432 \AA, \mathrm{C}-\mathrm{O}=1.376 \AA, \mathrm{C}-\mathrm{N}=1.346$ $\AA$, for compound 3, respectively (Table 3). Experimentally obtained bond distances of $\mathrm{C} 2=\mathrm{N} 3$ show $1.302 \AA$ (cal. $1.302 \AA$ ), $1.307 \AA$ (cal. $1.318 \AA$ ) and $1.303 \AA$ (cal. $1.301 \AA$ ), for compounds $\mathbf{1}, \mathbf{2}$ and $\mathbf{3}$, respectively. In addition to that, all three compounds display the electron delocalization over the atoms of $\mathrm{O} 1-\mathrm{C} 2-\mathrm{N} 3$. In all three compounds, the

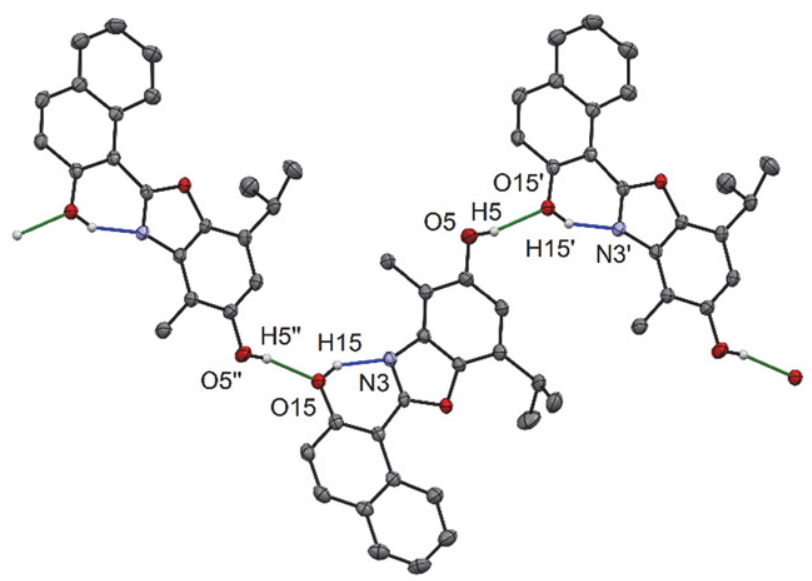

Figure 3. Hydrogen bond network in the crystal structure of 2 . The hydroxyl group in position 5 forms intermolecular hydrogen bonds (green) with the O15 oxygen on the naphthyl group (O5-H5 ‥O15') which in turn forms an intramolecular hydrogen bond (blue) with the neighboring benzoxazole $\mathrm{N} 3$ nitrogen atom $(\mathrm{O} 15-\mathrm{H} 15 \cdots \mathrm{N} 3)$. Thermal ellipsoids are drawn at $50 \%$ probability level and non-relevant hydrogen atoms are omitted. sum of bond angles around the $\mathrm{C} 2$ atom of the benzoxazole ring $(\mathrm{O} 1-\mathrm{C} 2-\mathrm{N} 3, \mathrm{O} 1-\mathrm{C} 2-\mathrm{C} 14$, and $\mathrm{N} 3-\mathrm{C} 2-\mathrm{C} 14=$ $359.99^{\circ}\left(\mathrm{cal} .360 .01^{\circ}\right.$ ) for compound $1,359.98^{\circ}$ (cal. $359.99^{\circ}$ ) for compound 2 and $359.98^{\circ}$ (cal. $360.00^{\circ}$ ) for compound 3 ) indicates $\mathrm{sp}^{2}$ hybridization and the bond an-
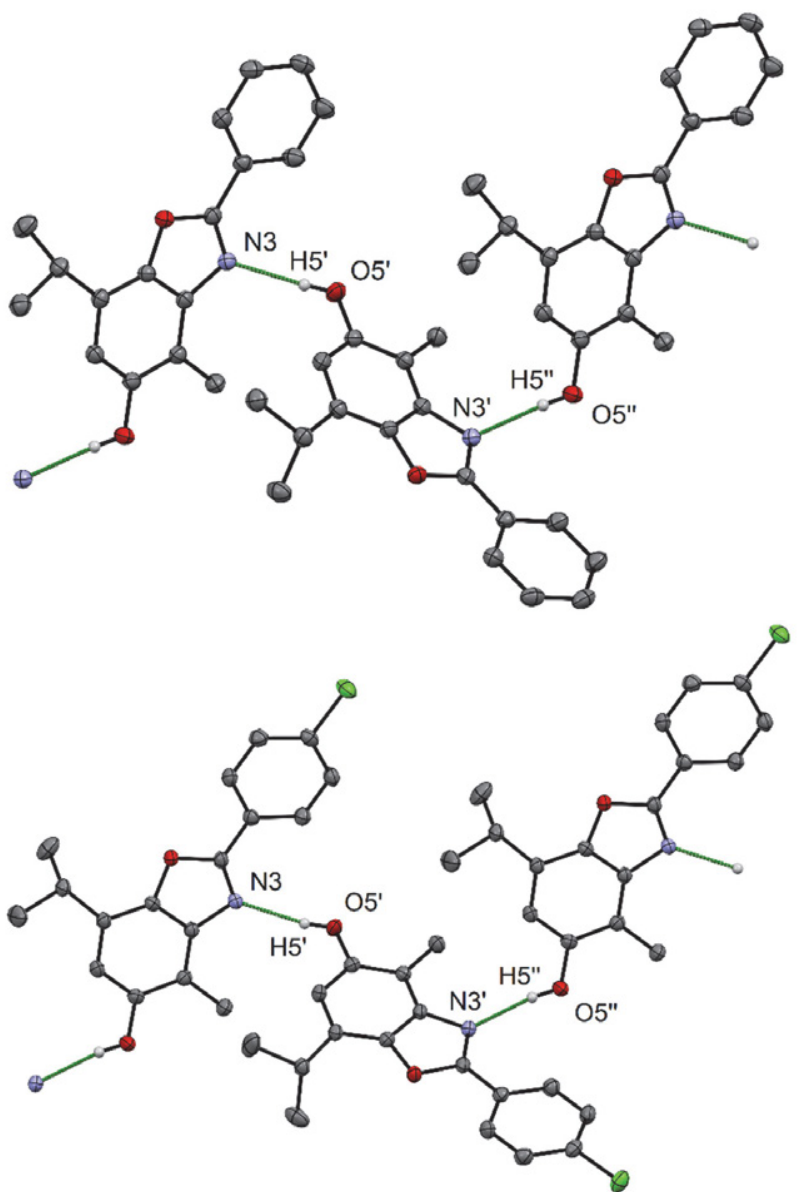

Figure 4. Hydrogen bond network in the crystal structures of compounds $\mathbf{1}$ (top) and $\mathbf{3}$ (bottom). The hydroxyl group in position 5 forms intermolecular hydrogen bonds (green) with the benzoxazole $\mathrm{N} 3$ nitrogen $\left(\mathrm{O}^{\prime}-\mathrm{H} 5^{\prime} \cdots \mathrm{N} 3\right)$. Thermal ellipsoids are drawn at $50 \%$ probability level and non-relevant hydrogen atoms are omitted. 
Table 1. Crystal data and structure refinement summary of compounds 2 and 3

\begin{tabular}{|c|c|c|}
\hline Compound & 2 & 3 \\
\hline Empirical formula & $\mathrm{C}_{21} \mathrm{H}_{19} \mathrm{NO}_{3}$ & $\mathrm{C}_{17} \mathrm{H}_{16} \mathrm{ClNO}_{2}$ \\
\hline$M_{w}$ & 333.37 & 301.76 \\
\hline$T, \mathrm{~K}$ & $150(2)$ & $150(2)$ \\
\hline Crystal system & monoclinic & monoclinic \\
\hline Space group & $P 22_{1} / \mathrm{n}$ & $P 2_{1} / \mathrm{n}$ \\
\hline$a, \AA$ & $6.7961(2)$ & $8.3718(2)$ \\
\hline$b, \AA$ & $15.9766(4)$ & $16.2112(1 a)$ \\
\hline$c, \AA$ & $15.7268(4)$ & $11.7098(1 \mathrm{a})$ \\
\hline$\alpha$, deg. & 90 & 90 \\
\hline$\beta$, deg. & $97.488(2)$ & $110.472(2)$ \\
\hline$\gamma$, deg. & 90 & 90 \\
\hline$V, \AA^{3}$ & $1693.03(8)$ & $1488.85(6)$ \\
\hline$Z$ & 4 & 4 \\
\hline$D_{\text {calc }}, \mathrm{g} / \mathrm{cm}^{3}$ & 1.308 & 1.346 \\
\hline$\mu, \mathrm{mm}^{-1}$ & 0.705 & 2.300 \\
\hline $\mathrm{F}(000)$ & 704 & 632 \\
\hline Crystal size, mm & $0.60 \times 0.10 \times 0.10$ & $0.20 \times 0.20 \times 0.20$ \\
\hline Color & colorless & yellow \\
\hline Data collected / unique & $5939 / 3190$ & $5382 / 5382$ \\
\hline$R_{\text {int }} / R_{\text {sigma }}$ & $0.0359 / 0.0452$ & $0.0195 / 0.0249$ \\
\hline Restraints / parameters & $0 / 231$ & $0 / 194$ \\
\hline$S$ & 1.059 & 1.043 \\
\hline$R_{1}, w R_{2}[\mathrm{I}>2 \sigma(\mathrm{I})]$ & $0.0595 / 0.1431$ & $0.0371 / 0.1010$ \\
\hline$R_{1}, w R_{2}$ (all data) & $0.0690 / 0.1558$ & $0.0404 / 0.1047$ \\
\hline Larg. diff. peak/hole $\left(\mathrm{e} \cdot \AA^{-3}\right)$ & $0.35 /-0.58$ & $0.28 /-0.33$ \\
\hline
\end{tabular}

gle of $\mathrm{C} 2-\mathrm{N} 3-\mathrm{O} 1, \mathrm{C} 9-\mathrm{C} 8-\mathrm{C} 7$, and $\mathrm{C} 8-\mathrm{C} 9-\mathrm{C} 4$ deviates from $120^{\circ}$ due to the presence of substituents.

\section{2. Intra- and Intermolecular Interactions and Crystal Packing Analysis}

The crystal structures of compounds $\mathbf{1}, \mathbf{2}$ and $\mathbf{3}$ are stabilized via intramolecular $\mathrm{O}-\mathrm{H} \cdots \mathrm{N}$ hydrogen bond and intermolecular $\mathrm{O}-\mathrm{H} \cdots \mathrm{N}, \mathrm{O}-\mathrm{H} \cdots \mathrm{O}$, and $\mathrm{O}-\mathrm{H} \cdots \mathrm{N}$ hydrogen bonds (Table 2). The crystal structure of compound 2

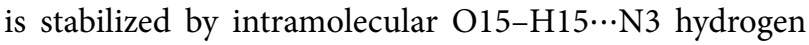
bond, in which the hydroxylic $\mathrm{O} 15$ acts as a donor and makes a hydrogen bond with imine N3 with the bond length of $2.477 \AA$ (Figure 3).

The crystal packing is stabilized by one intramolecular $\mathrm{O} 15-\mathrm{H} 15 \cdots \mathrm{N} 3$ hydrogen bond with the bond distances of $2.477 \AA$ (cal. $2.640 \AA$ ), whereas in compounds 1, 2 and 3, three intermolecular hydrogen bonds contribute to crystal packing such as $\mathrm{O} 5-\mathrm{H} 5 \cdots \mathrm{N} 3$ with the bond distances of $2.811 \AA$ (2.850 $\mathrm{A}), \mathrm{O} 15-\mathrm{H} 15 \cdots \mathrm{O} 152.711 \AA$ (cal. $2.900 \AA$ ) and $\mathrm{O} 5-\mathrm{H} 5 \cdots \mathrm{N} 32.800 \AA$ (2.850 $\mathrm{A})$, respectively. Atom N3 acts as a hydrogen bond acceptor for $\mathrm{O}-\mathrm{H} \cdots \mathrm{N}$

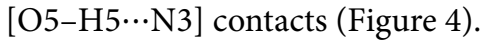

Crystal data and structure refinement summary of compounds 2 and 3 are given in Table 1.

The same data for compound $\mathbf{1}$ are presented in our previous paper. $^{16}$

Table 2. Selected distances and angles

\begin{tabular}{|c|c|c|c|c|c|c|c|c|c|c|}
\hline \multirow{2}{*}{$\begin{array}{l}\text { Com- } \\
\text { pound }\end{array}$} & \multirow[t]{2}{*}{ Cpd (D-H...A) } & \multirow[t]{2}{*}{ type } & \multicolumn{2}{|c|}{ d(D-H) (̊̊) } & \multicolumn{2}{|c|}{$d(D \cdots A)(\AA)$} & \multicolumn{2}{|c|}{ 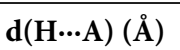 } & \multicolumn{2}{|c|}{$\varphi(\mathrm{D}-\mathrm{H} \cdots \mathrm{A})\left(^{\circ}\right)$} \\
\hline & & & Exp. & Calc. & Exp. & Calc. & Exp. & Calc. & Exp. & Calc. \\
\hline 1 & $(\mathrm{O} 5-\mathrm{H} 5 \cdots \mathrm{N} 3)$ & inter & 0.84 & 0.90 & 2.8105 & 2.8500 & 1.97 & 1.90 & 175 & 172.9 \\
\hline 2 & (O5-H5 ‥O15) & inter & 0.84 & 0.90 & 2.7108 & 2.9000 & 1.88 & 2.00 & 168 & 166.5 \\
\hline 2 & $(\mathrm{O} 15-\mathrm{H} 15 \cdots \mathrm{N} 3)$ & intra & 0.84 & 0.90 & 2.4772 & 2.6400 & 1.72 & 1.74 & 149 & 147.0 \\
\hline 3 & $(\mathrm{O} 5-\mathrm{H} 5 \cdots \mathrm{N} 3)$ & inter & 0.84 & 0.90 & 2.8004 & 2.8500 & 1.97 & 1.87 & 170 & 174.0 \\
\hline
\end{tabular}

Table 3. Bond lengths [A] and angles [deg] of compounds 1, 2 and 3

\begin{tabular}{|c|c|c|c|c|c|c|}
\hline \multirow{2}{*}{ Bond length and angles } & \multicolumn{2}{|c|}{ Compound 1} & \multicolumn{2}{|c|}{ Compound 2} & \multicolumn{2}{|r|}{ Compound 3} \\
\hline & $\begin{array}{l}\text { Exp. } \\
6-31 G(d\end{array}$ & Cal. $6-31 G^{\star *} 6-31+G^{*}$ & $\begin{array}{l}\text { Exp. } \\
6-31 G(d\end{array}$ & Cal. $6-31 G^{\star *} 6-31+G^{*}$ & $\begin{array}{l}\text { Exp. } \\
6-31 G(c\end{array}$ & $\begin{array}{c}\text { Cal. } \\
\text { (d) } 6-31 \mathrm{G}^{* *} 6-31+\mathrm{G}^{*}\end{array}$ \\
\hline $\mathrm{O}(1)-\mathrm{C}(2)$ & 1.364 & 1.3701 .3711 .369 & 1.363 & 1.3651 .3621 .363 & 1.367 & 1.3701 .3681 .371 \\
\hline $\mathrm{O}(5)-\mathrm{C}(5)$ & 1.368 & 1.3711 .3721 .371 & 1.361 & 1.3691 .3701 .368 & 1.366 & 1.3691 .3671 .369 \\
\hline $\mathrm{C}(9)-\mathrm{N}(3)$ & 1.403 & 1.3951 .3941 .396 & 1.388 & 1.3871 .3881 .389 & 1.406 & 1.4001 .4021 .404 \\
\hline$C(2)-N(3)$ & 1.302 & 1.3021 .3031 .301 & 1.307 & 1.3081 .3071 .309 & 1.303 & 1.3011 .3021 .304 \\
\hline $\mathrm{C}(2)-\mathrm{C}(14)$ & 1.461 & 1.4601 .4611 .360 & 1.458 & 1.4541 .4551 .457 & 1.457 & 1.4561 .4571 .459 \\
\hline $\mathrm{O}(5)-\mathrm{C}(5)-\mathrm{C}(4)$ & 116.53 & 115.90115 .92115 .95 & 116.44 & 115.80115 .83115 .82 & 116.44 & 120.01119 .98119 .97 \\
\hline $\mathrm{C}(8)-\mathrm{C}(9)-\mathrm{N}(3)$ & 108.29 & 108.89108 .90108 .91 & 107.76 & 107.95107.96107.97 & 108.22 & 108.80108 .81108 .83 \\
\hline $\mathrm{C}(4)-\mathrm{C}(9)-\mathrm{N}(3)$ & 130.16 & 129.63129 .65129 .67 & 129.42 & 130.09130 .10130 .08 & 130.42 & 129.90129 .94129 .97 \\
\hline $\mathrm{N}(3)-\mathrm{C}(2)-\mathrm{O}(1)$ & 114.97 & 114.89114 .90114 .91 & 113.79 & 113.53113 .55113 .53 & 114.83 & 114.87114 .89114 .92 \\
\hline $\mathrm{N}(3)-\mathrm{C}(2)-\mathrm{C}(14)$ & 127.83 & 127.51127 .53127 .55 & 123.26 & 124.73124 .74124 .76 & 128.55 & 127.73127 .98127 .97 \\
\hline $\mathrm{O}(1)-\mathrm{C}(2)-\mathrm{C}(14)$ & 117.19 & 117.60117 .61117 .59 & 122.93 & 121.99122 .00122 .02 & 116.60 & 117.56117 .98117 .97 \\
\hline
\end{tabular}


Table 4. Calculated HOMO and LUMO energy values in compounds 1, 2 and 3

\begin{tabular}{|c|c|c|c|c|c|c|c|c|c|}
\hline \multirow{3}{*}{ Parameters } & \multicolumn{9}{|c|}{ Compound } \\
\hline & & 1 & & & 2 & & & 3 & \\
\hline & $6-31 G^{\star}(d)$ & $6-31 G^{\star *}$ & $6-31+G^{*}$ & $6-31 G^{\star}(d)$ & $6-31 G^{\star *}$ & $6-31+\mathrm{G}^{\star}$ & $6-31 G^{\star}(\mathrm{d})$ & $6-31 \mathrm{G}^{\star *}$ & $6-31+\mathrm{G}^{\star}$ \\
\hline $\mathrm{E}_{\text {номо }}(\mathrm{eV})$ & -5.61 & -5.61 & -5.62 & -5.40 & -5.42 & -5.44 & -5.71 & -5.73 & -5.74 \\
\hline $\mathrm{E}_{\mathrm{LUMO}}(\mathrm{eV})$ & -1.33 & -1.34 & -1.35 & -1.61 & -1.62 & -1.63 & -1.55 & -1.57 & -1.58 \\
\hline Energy gap $(\Delta)$ & 4.28 & 4.27 & 4.27 & 3.79 & 3.80 & 3.81 & 4.16 & 4.16 & 4.16 \\
\hline
\end{tabular}

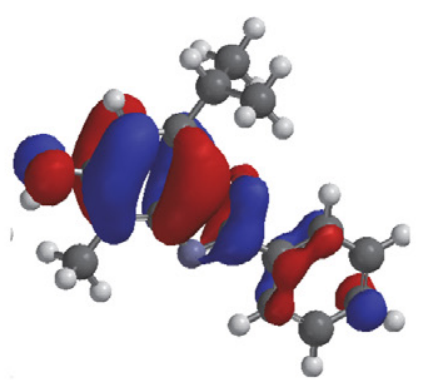

HOMO

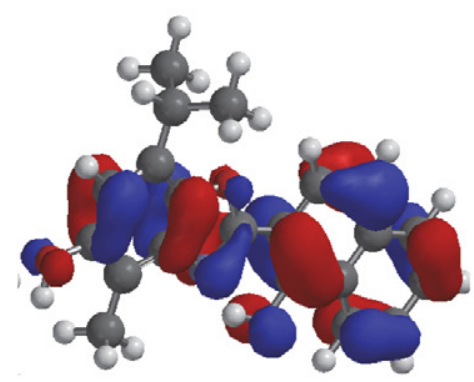

HOMO

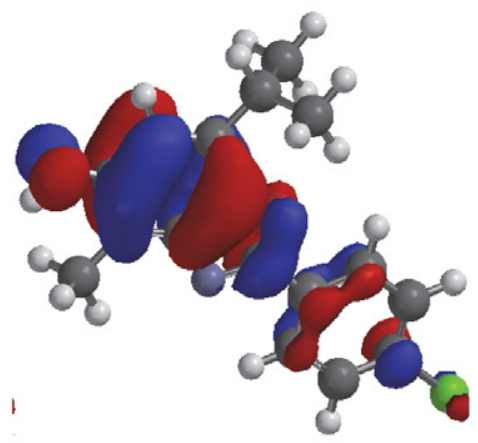

HOMO

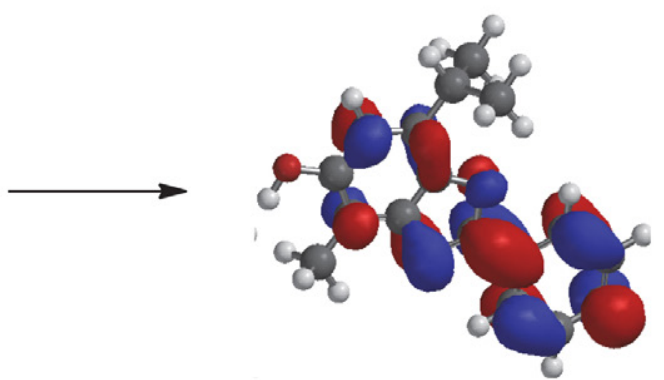

1

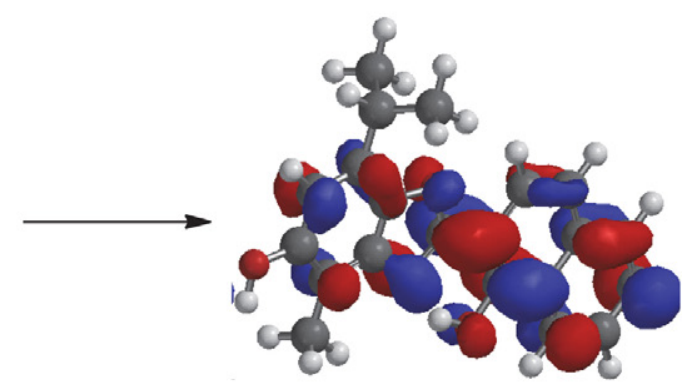

2

LUMO

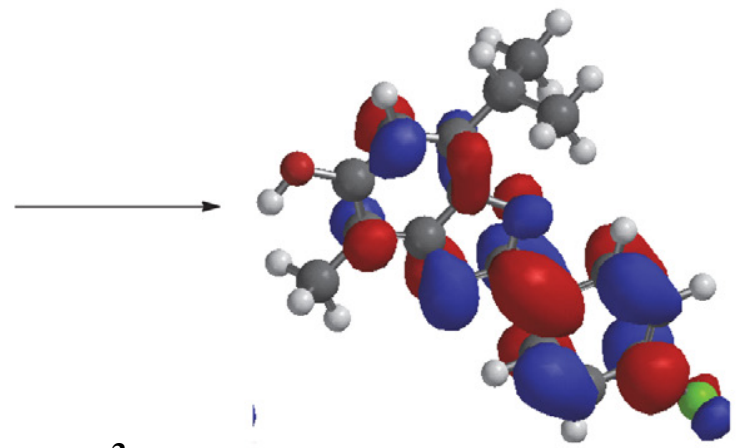

LUMO

Figure 5. Atomic orbitals of HOMO to LUMO transition of the compounds 1, 2 and $\mathbf{3}$

\section{3. Molecular Orbital Analysis}

The HOMO-LUMO energy gap of a molecule will play a crucial role in deciding its bioactive properties and is a very important parameter for quantum chemistry. The HOMO energy distinguishes the capacity of electron donor, whereas LUMO energy characterizes the capacity of electron acceptor, and the gap distinguishes the chemical stability. ${ }^{24}$ biologically active methylxanthines were investigated. All calculations were performed at B3LYP/6-31G* level of theory. The electronic chemical potential, highest occupied molecular orbital (HOMO The HOMO-LUMO energy gap for the compounds 1, 2 and 3 was calculated by $6-31 \mathrm{G}^{*}(\mathrm{~d})$ basis set and the values are $4.27 \mathrm{eV}$ for compound $1,3.80 \mathrm{eV}$ for compound 2 and $4.15 \mathrm{eV}$ for compound 3 . The energies of HOMO and LUMO and the HOMO-LUMO energy gap are given in Table 4. The HOMO-LUMO orbital scheme of compounds 1, 2 and 3 are shown in Figure 5 (positive phases are red and the negatives ones are blue). The value of the HOMO and LUMO energy gap in compound $\mathbf{2}$ is the smallest, indicating that the molecule is more stable compared to 
compounds 3 and $\mathbf{1}$. The lower value of the HOMO and LUMO energy gap explains the eventual charge transfer interaction taking place within the molecules. ${ }^{25}$ The HOMO to LUMO transition indirectly explains the descriptor of electron donor and acceptor in order to understand their interacting ability with their target molecules. Compound 2, which is the most chemically reactive, showed the lowest antitumor activity in our previous study. ${ }^{16}$

\section{Conclusions}

We presented the structural details of benzoxazole compounds, $1 \quad\left(\mathrm{C}_{17} \mathrm{H}_{17} \mathrm{NO}_{2}\right), 2\left(\mathrm{C}_{21} \mathrm{H}_{19} \mathrm{NO}_{3}\right)$ and 3 $\left(\mathrm{C}_{17} \mathrm{H}_{16} \mathrm{ClNO}_{2}\right)$, by using single crystal X-ray diffraction data. DFT calculation was performed with a standards $6-31 G^{*}(d), 6-31 G^{* *}$ and $6-31+G^{*}$ basis set to analyze the molecular geometry and compare with experimentally available X-ray crystal data of investigated compounds. The calculated HOMO-LUMO energy gap in compound $\mathbf{2}$ for basis set $6-31 \mathrm{G}^{*}(\mathrm{~d})$ is 3.79 , for $6-31 \mathrm{G}^{* *}$ is 3.8 , and $6-31+\mathrm{G}^{*}$ is 3.8 . This small gap value indicates that compound 2 is chemically more reactive compared to compounds $\mathbf{1}$ and $\mathbf{3}$. Chemical reactivity values, such as chemical hardness, chemical potential electronegativity and electrophilicity index and HOMO-LUMO energy gap obtained theoretically, can be used to understand the biological activity of the title compound. Further, the crystal structure is stabilized by both intra- and intermolecular hydrogen bonds in which intermolecular N$\mathrm{H} \cdot \cdots \mathrm{O}$ hydrogen bond generates $\mathrm{N} 3$ and $\mathrm{O} 7$ chain motif in compounds 1, 2 and 3, respectively. The calculated bond lengths and bond angles of $\mathbf{1}, \mathbf{2}$ and $\mathbf{3}$ show good agreement to the experimental values obtained by $\mathrm{X}$-ray crystal diffraction. The values obtained theoretically show some correlations with previous results of biological activity testing.

\section{Acknowledgements}

The authors are grateful to financial support from Federal Ministry of education and science in Bosnia and Herzegovina (grant number: 05-39-3629-1/14, Most: Završnik D. "Modeliranje i doking studije novih potentnih azometinskih derivata timokinona i njihovih organometalnih kompleksa". Ministarstvo za obrazovanje, nauku, kulturu i sport FBiH, 2014-2015. godine (Mostar, 22.12.2014. godine, Ugovor broj: 05-39-3629-1/14).

We thank EN-FIST Centre of Excellence, Trg OF 13, 1000 Ljubljana, Slovenia for using SuperNova diffractometer and Slovenian Research Agency for financial support (P1-0175).

\section{References}

1. C. S. Demmer, L. Bunch, Eur. J. Med. Chem. 2015, 97, 778785. DOI:10.1016/j.ejmech.2014.11.064
2. S. Laeeq, A. K. Sirbaiya, H. H. Siddiqui, Indo. Am. J. Pharm. Res. 2013, 3, 1660-1682.

3. H. Song, C. Rao, Z. Deng, Y. Yi, J. H. Naismith, Angew. Chem. Int. Ed Engl., 2020, 59, 6054-6061.

DOI:10.1002/anie.201915685

4. K. Seth, S. K. Garg, R. Kumar, P. Purohit, V. S. Meena, R. Goyal, U. C. Banerjee, A. K. Chakraborti, ACS Med. Chem. Lett., 2014, 5, 512-516. DOI:10.1021/ml400500e

5. C. Sheng, X. Che, W. Wang, S. Wang, Y. Cao, J. Yao, Z. Miao, W. Zhang, Eur. J. Med. Chem., 2011, 46, 1706-1712.

DOI:10.1016/j.ejmech.2011.01.075

6. S. M. Rida, F. A. Ashour, S. A. M. El-Hawash, M. M. ElSemary, M. H. Badr, M. A. Shalaby, Eur. J. Med. Chem., 2005, 40, 949-959. DOI:10.1016/j.ejmech.2005.03.023

7. C. Hohmann, K. Schneider, C. Bruntner, E. Irran, G. Nicholson, A. T. Bull, A. L. Jones, R. Brown, J. E. M. Stach, M. Goodfellow, W. Beil, M. Krämer, J. F. Imhoff, R. D. Süssmuth, H.-P. Fiedler, J. Antibiot. (Tokyo), 2009, 62, 99-104.

DOI:10.1038/ja.2008.24

8. E. Oksuzoglu, B. Tekiner-Gulbas, S. Alper, O. Temiz-Arpaci, T. Ertan, I. Yildiz, N. Diril, E. Sener-Aki, I. Yalcin, J. Enzyme Inhib. Med. Chem., 2008, 23, 37-42.

DOI:10.1080/14756360701342516

9. D. Kumar, M. R. Jacob, M. B. Reynolds, S. M. Kerwin, Bioorg. Med. Chem., 2002, 10, 3997-4004.

DOI:10.1016/S0968-0896(02)00327-9

10. Y. An, E. Lee, Y. Yu, J. Yun, M. Y. Lee, J. S. Kang, W.-Y. Kim, R. Jeon, Bioorg. Med. Chem. Lett., 2016, 26, 3067-3072. DOI:10.1016/j.bmcl.2016.05.017

11. N. Aggarwal, A. Kaur, K. Anand, H. Kumar, S. R. Wakode, Int. J. Pharm. Sci. Res., 2017, 2, 01-05.

12. H. G. Bray, R. C. Clowes, W. V. Thorpe, Biochem. J., 1952, 51, 70-78. DOI:10.1042/bj0510070

13. C. J. McElhinny, A. H. Lewin, S. W. Mascarella, S. Runyon, L. Brieaddy, F. I. Carroll, Bioorg. Med. Chem. Lett., 2012, 22, 6661-6664. DOI:10.1016/j.bmcl.2012.08.109

14. M. Ono, K. Yamakawa, H. Kobayashi, I. Itoh, ChemInform, 1988, 19, 92-93.

15. R. Haunschild, A. Barth, W. Marx, J. Cheminformatics, 2016, 8,1-12. DOI:10.1186/s13321-016-0166-y

16. U. Glamočlija, S. Padhye, S. Špirtović-Halilović, A. Osmanović, E. Veljović, S. Roca, I. Novaković, B. Mandić, I. Turel, J. Kljun, S. Trifunović, E. Kahrović, S. Kraljević Pavelić, A. Harej, M. Klobučar, D. Završnik, Molecules, 2018, 23, 3297. DOI:10.3390/molecules23123297

17. G. M. Sheldrick, Acta Crystallogr. Sect. Found. Adv., 2015, 71, 3-8. DOI:10.1107/S2053273314026370

18. G. M. Sheldrick, Acta Crystallogr. Sect. C Struct. Chem., 2015, 71,3-8. DOI:10.1107/S2053229614024218

19. O. V. Dolomanov, L. J. Bourhis, R. J. Gildea, J. A. K. Howard, H. Puschmann, J. Appl. Crystallogr., 2009, 42, 339-341. DOI:10.1107/S0021889808042726

20. A. L. Spek, Acta Crystallogr. D Biol. Crystallogr., 2009, 65, 148-155. DOI:10.1107/S090744490804362X

21. C. F. Macrae, P. R. Edgington, P. McCabe, E. Pidcock, G. P. Shields, R. Taylor, M. Towler, J. van de Streek, J. Appl. Crystal- 
logr., 2006, 39, 453-457. DOI:10.1107/S002188980600731X

22. F. H. Allen, O. Kennard, D. G. Watson, L. Brammer, A. G. Orpen, R. Taylor, J. Chem. Soc. Perkin Trans. 2, 1987, S1-S19. DOI:10.1039/p298700000s1

23. M. W. Schmidt, K. K. Baldridge, J. A. Boatz, S. T. Elbert, M. S. Gordon, J. H. Jensen, S. Koseki, N. Matsunaga, K. A. Nguyen, S. Su, T. L. Windus, M. Dupuis, J. A. Montgomery, J. Comput. Chem., 1993, 14, 1347-1363. DOI:10.1002/jcc.540141112
24. M. Salihović, Š. Huseinović, S. Špirtović-Halilović, A. Osmanović, A. Dedić, Z. Ašimović, D. Završnik, Bull. Chem. Technol. Bosnia Herzeg., 2014, 31-36.

25. A. A. H. Kadhum, A. A. Al-Amiery, A. Y. Musa, A. B. Mohamad, Int. J. Mol. Sci., 2011, 12, 5747-5761.

DOI:10.3390/ijms12095747

\section{Povzetek}

$\mathrm{Z}$ rentgensko difrakcijo na monokristalih smo določili kristalne strukture biološko aktivnih derivatov benzoksazola. Z DFT izračuni, pri katerih smo uporabili standardne bazne sete $6-31 G^{\star}(d), 6-31 G^{\star *}$ in $6-31+G^{*}$, smo analizirali molekulsko geometrijo in primerjali rezultate računskih modelov z eksperimentalno določenimi kristalnimi strukturami spojin. Izračunana HOMO-LUMO energijska vrzel v spojini 2 (2-(2-hidroksinaftalen-1-il)-4-metil-7-izopropil-1,3-benzoksazol-5-ol) je 3,80 eV, kar je najmanj med preučevanimi spojinami in nakazuje na večjo kemijsko reaktivnost spojine v primerjavi s spojinama 1 (4-metil-2-fenil-7-izopropil-1,3-benzoksazol-5-ol) in 3 (2-(4-klorofenil)-4-metil-7-izopropil-1,3-benzoksazol-5-ol). Kristalne strukture so stabilizirane $\mathrm{z}$ intra- in intermolekularnimi vodikovimi vezmi, pri čemer se v vseh strukturah spojin 1, 2 in 3 pojavi verižni strukturni motiv $\mathrm{O}-\mathrm{H} \cdots \mathrm{N}$ vodikovih vezi. Računski modeli dolžin in kotov kemijskih vezi se izjemno dobro skladajo $\mathrm{z}$ eksperimentalno določenimi vrednostmi eksperimenta rentgenske difrakcije na monokristalih.

Except when otherwise noted, articles in this journal are published under the terms and conditions of the Creative Commons Attribution 4.0 International License 